\title{
AKTIVITAS NEFROPROTEKTIF EKSTRAK ETANOL BUNGA TELANG (Clitoria ternatea L.) TERHADAP TIKUS YANG DIINDUKSI PARASETAMOL
}

\author{
Dichy Nuryadin Zain*, Anisa Pebiansyah, Ade Yeni Aprilia \\ Program Studi Farmasi, STIKes Bakti Tunas Husada Tasikmalaya \\ *Email: dichynuryadinzain@stikes-bth.ac.id \\ Received: 14/07/2021, Revised: 29/07/2021, Accepted: 04/08/2021, Published: 18/08/2021
}

\begin{abstract}
ABSTRAK
Parasetamol merupakan obat yang biasa digunakan sebagai antipiretik dan analgesik tetapi dapat bersifat nefrotoksik apabila digunakan secara berlebihan. Bunga Telang (Clitoria ternatea L.) diketahui berpotensi sebagai nefroprotektor karena mengandung senyawa metabolit sekunder yang bersifat antioksidan. Tujuan dari penelitian ini adalah untuk mengetahui dosis optimal ekstrak etanol Bunga Telang (Clitoria ternatea L.) sebagai nefroprotektor pada tikus putih yang diinduksi oleh parasetamol. Perlakuan pada tikus dikelompokkan menjadi lima kelompok perlakuan, yaitu kontrol normal (aquades), kontrol negatif (parasetamol), kontrol positif (Curliv), dan kelompok ekstrak (100 mg/kg, $200 \mathrm{mg} / \mathrm{kg}$ dan $300 \mathrm{mg} / \mathrm{kg}$ ). Hasil penelitian diperoleh bahwa ekstrak etanol bunga telang pada dosis $300 \mathrm{mg} / \mathrm{kg}$ mengalami terjadinya penurunan kadar ureum jika dibandingkan dengan kontrol. Dilihat berdasarkan hasil yang diperoleh ekstrak etanol Bunga Telang (Clitoria ternatea L.) memiliki efek nefroprotektor melalui penurunan kadar ureum pada tikus yang diinduksi oleh parasetamol.
\end{abstract}

Kata kunci : nefroprotektor, bunga telang, ureum

\begin{abstract}
Paracetamol is a drug commonly used as an antipyretic and analgesic but can be nephrotoxic if used in excess. Telang flower (Clitoria ternatea L.) is known to have potential as a nephroprotector because it contains secondary metabolites that are antioxidants. The purpose of this study was to determine the optimal dose of ethanol extract of Bunga Telang (Clitoria ternatea L.) as a nephroprotector in white rats induced by paracetamol. The rats were grouped into five treatment groups, namely normal control (aquades), negative control (paracetamol), positive control (Curliv), and extract group (100 mg/kg, $200 \mathrm{mg} / \mathrm{kg}$ and $300 \mathrm{mg} / \mathrm{kg})$. The results showed that the ethanol extract of telang flower at a dose of $300 \mathrm{mg} / \mathrm{kg}$ experienced a decrease in ureum levels when compared to the control. Judging from the results obtained, the ethanolic extract of Bunga Telang (Clitoria ternatea L.) has a nephroprotector effect by reducing ureum levels in rats induced by paracetamol.
\end{abstract}

Keywords: nephroprotector, butterfly pea flower, ureum 


\section{PENDAHULUAN}

Parasetamol merupakan obat yang termasuk kedalam obat golongan bebas. Obat ini biasa digunakan oleh masyarakat umum untuk menghilangkan nyeri ringan, nyeri sedang dan pada kondisi demam ringan (Syafitri, 2017). Namun masyarakat pada umumnya tidak mengetahui dampak pemakain obat ini apabila digunakan secara sembarang dan terus menerus. Parasetamol akan menginduksi terjadinya hepatotoksisitas dan nefrotoksisitas karena kurangnya GSH untuk detoksifikasi (Dokumacıoğlu et al., 2016; Madinah et al., 2015; Cone et al., 2008). Nefrotoksisitas parasetamol telah dipelajari dengan ditandai oleh bukti morfologis dan fungsional cedera tubulus proksimal pada manusia dan hewan percobaan. Karena tubulus proksimal adalah tempat paling umum yang dapat dicederai oleh obat, pemahaman mengenai efek toksisitas tubulus proksimal obat sangat penting dalam evaluasi obat. Informasi tentang mekanisme toksisitas lebih lanjut akan membantu hubungan struktur-aktivitas dan meminimalkan risiko kerusakan ginjal klinis (Cekmen et al., 2009; Amalia, 2017; Kusnadi, 2018).

$$
\text { Parasetamol merupakan obat }
$$
antiinflamasi non-steroid (AINS), yang pada pemberian secara oral, sekitar $63 \%$ dimetabolisme di hati melalui glukuronidasi dan 34\% melalui sulfasi. Metabolit tersebut kemudian diekskresikan melalui ginjal (Canayakin et al., 2016). Pada dosis terapetik kurang dari $5 \%$ persen dari parasetamol dioksidasi oleh sistem enzim sitokrom P-450 mikrosomal menjadi senyawa antara reaktif, $\mathrm{N}$-acetyl-p-benzoquinone imine (NAPQI). Pada dosis terapi, metabolit elektrofilik ini kemudian didetoksifikasi melalui reaksi reduksi oleh intraseluler glutation (GSH) dan selanjutnya diekskresikan sebagai asam merkapturat (Mazer et al., 2008; Canayakin et al., 2016; Stollings et al., 2016).

Beberapa penelitian tentang bunga telang membuktikan bahwa Bunga Telang (Clitoria ternatea L.) memiliki efek nefroprotektor terhadap histologi nefron mencit dikarenakan mempunyai senyawa flavonoid sebagai antioksidan. Penelitian membuktikan bahwa pemberian ektrak bunga telang berpengaruh terhadap penurunan aktivitas telomerase dan apoptosis pada karsinogenesis tikus. Bunga telang dikenal mempunyai aktifitas farmakologi diantaranya sebagai antioksidan (Cahyaningsih, 2017; Andriani, 2020; Marpaung, 2020; Pratiwi, 2020), antibakteri, anti inflamasi, antidiabetes, antihistamin, antikanker, antiparasit, immunomodulator, 
dan potensi berperan dalam SSP (Budiasih, 2017; Palimbong, 2020).

Bunga Telang (Clitoria ternatea L.) mengandung senyawa antosianin dengan aktivitas antioksidan yang tinggi (Winarti, 2020). Selain fungsinya sebagai antioksidan, flavonoid juga dapat membantu pensinyalan sel, yang memiliki efek biologis untuk memodulasi jalur sinyal pada sel atau jalur tranduksi sinyal (El-Shafey, 2015). Jalur ini mengatur proses banyak sel, termasuk pertumbuhan, poliferasi, dan kematian sel. Penelitian menunjukkan bahwa ROS menginduksi apoptosis berbagai jenis sel. Potensi dari antioksidan ekstrak Bunga Telang (Clitoria ternatea L.) dengan kandungan flavonoid dilaporkan dapat menghambat peroksidasi lipid, sehingga dapat menangkal radikal bebas pada tubuh (Wang et al, 2017; Santos-Sánchez, 2019). Tujuan dari penelitian ini adalah untuk mengetahui dosis optimal ekstrak etanol Bunga Telang (Clitoria ternatea L.) sebagai nefroprotektor pada tikus putih yang diinduksi oleh parasetamol.

\section{METODE PENELITIAN}

\section{Alat dan Bahan}

Alat yang digunakan dalam penelitian ini adalah spuit $5 \mathrm{~mL}$ (GidCare), sonde oral, kain lap, tissue, toples, mikropipet (Accumax Lab Technology), Lithium Heparin (Golden Vac), kuvet (Quartz SUPRASIL) ${ }^{\circledR}, \quad$ Spektrofotometer Genesys 10S UV-VIS (Thermo), Fotometer Semi-auto Chemistry Analyzer (WP 9200).

Bahan yang digunakan dalam penelitian ini adalah Ekstrak Etanol Bunga Telang, etanol 70\% (Brataco), Eter (Brataco), Aquadest (Brataco), Parasetamol (Sigma Aldrich), Ekstrak Schizandrae fructus $135 \mathrm{mg}$; Ekstrak Kurkuma xanthorrhizae rhizoma $150 \mathrm{mg}$; Ekstrak Liquiritiae radix $135 \mathrm{mg}$; Kolin bitartrat 150 mg; Vit-B6 2 mg (Curliv Plus Kaplet).

\section{Jalannya Penelitian}

\section{Persiapan Hewan Uji}

Tikus yang akan digunakan pada penelitian ini sudah melalui protokol kode etik penelitian kesehatan KEPK STIKes Bakti Tunas Husada Tasikmalaya dengan nomor keterangan layak etik No.045/kepkbth/12/2020.

Tikus putih dipelihara dalam kendang yang berisi lima ekor per kandang. Tikus putih diaklimatisasi selama 7 hari di laboratorium pada suhu $27 \pm 2^{\circ} \mathrm{C}$ di bawah siklus pencahayaan 12 jam terang/gelap. Tikus putih diberi pakan tikus standar dan air minum ad libitum setiap hari. 


\section{Penentuan Dosis}

Penelitian ini dilakukan secara eksperimental menggunakan Rancangan Acak Kelompok (RAK) dengan ulangan lima yang terdiri dari 7 kelompok perlakuan dengan rincian sebagai berikut:

a. Kontrol normal: tikus putih hanya diberi akuades tanpa diberi parasetamol dan ekstrak selama 7 hari

b. Kontrol positif: tikus putih diberi parasetamol $750 \mathrm{mg} / \mathrm{kg}$ kemudian Curliv $37 \mathrm{mg} / \mathrm{kg}$ masing-masing selama 7 hari

c. Kontrol negatif: tikus putih hanya diberi parasetamol $750 \mathrm{mg} / \mathrm{kg}$ selama 7 hari

d. Dosis 1: tikus putih diberi parasetamol $750 \mathrm{mg} / \mathrm{kg}$ kemudian ekstrak etanol bunga telang dengan konsentrasi 100 $\mathrm{mg} / \mathrm{kg}$ tikus masing-masing selama 7 hari

e. Dosis 2: tikus putih diberi parasetamol $750 \mathrm{mg} / \mathrm{kg}$ kemudian ekstrak etanol bunga telang dengan konsentrasi 200 $\mathrm{mg} / \mathrm{kg}$ tikus masing-masing selama 7 hari

f. Dosis 3: tikus putih diberi parasetamol $750 \mathrm{mg} / \mathrm{kg}$ kemudian ekstrak etanol bunga telang dengan konsentrasi 300 $\mathrm{mg} / \mathrm{kg}$ tikus masing-masing selama 7 hari

Pemberian perlakuan dilakukan secara oral dengan volume yang telah disesuaikan berdasarkan berat badan tikus. Untuk tikus pada Dosis I, II, dan II terlebih dahulu diberikan induksi parasetamol kemudian diberikan ekstrak etanol bunga telang.

3. Pengambilan Darah dan Pengukuran Pengambilan darah dilakukan pada hari ke-8. Tikus dimasukkan ke dalam wadah yang berisikan kapas yang sebelumnya diberikan eter. Hal ini dilakukan sebagai langkah anestesi pada tikus. Sampel darah diambil dari sinus retro-orbital. Sampel darah ditampung ke dalam tabung heparin kemudian disentrifus. Setelah disentrifus kemudian dilakukan pemeriksaan ureum dengan menggunakan fotometer.

4. Analisis Data

Analisis data dikumpulkan dari hasil percobaan dengan mengukur kadar ureum dalam darah pada tikus yang telah diberi larutan uji, kemudian dianalisis secara statistik dengan menggunakan GraphPad versi 8.3.0 untuk menentukan perbedaan yang signifikan dalam semua parameter yang diujikan. Nilai $p<0,05$ dianggap sebagai nilai yang signifikan secara statistik.

\section{HASIL DAN PEMBAHASAN}

Efek nefrotoksik pemberian ekstrak etanol bunga telang dengan pemberian tiga dosis yaitu $100 \mathrm{mg} / \mathrm{kg}, 200 \mathrm{mg} / \mathrm{kg}, 300$ $\mathrm{mg} / \mathrm{kg}$ dan kelompok kontrol pada masing- 
masing tikus diperoleh data pada uji fungsi ginjal (pemeriksaan ureum serum) sebagaimana ditunjukkan pada Gambar 1.

Nilai ureum darah tikus setelah pemberian ekstrak dengan dosis $100 \mathrm{mg} / \mathrm{kg}$, 200 mg/kg, 300 mg/kg dan kelompok kontrol pada masing-masing tikus, diperoleh ratarata kadar ureum yaitu pada kelompok kontrol normal sebesar 45,8 $\pm 5,22$; kelompok kontrol positif sebesar 29,8 \pm 9,20; kelompok kontrol negatif sebesar 40,6 \pm 10,74. Sedangkan pada kelompok perlakuan dosis I sebesar $26 \pm 5,20$; kelompok dosis II sebesar $35 \pm 13,27$; kelompok dosis III sebesar 25,6 \pm 5,55. Dari data statistik ANOVA satu arah tersebut pada tiap kolom kadar ureum berbeda sangat signifikan $(\mathrm{P}<0,05)$.

Penelitian ini menggunakan ekstrak etanol bunga telang yang digunakan sebagai nefrotektor pada ginjal tikus. Penggunaan hewan uji dengan galur, umur, jumlah dan berat yang sama dapat meminimalkan variasi biologi sehingga data layak untuk dibandingkan. Hewan uji disimpan dalam kendang terpisah berisi lima ekor per kandang. Tikus putih diaklimatisasi selama 7 hari di laboratorium pada suhu $27 \pm 2^{\circ} \mathrm{C}$ di bawah siklus pencahayaan 12 jam terang/gelap. Tikus putih diberi pakan tikus standar dan air minum ad libitum setiap hari.
(Anjani, 2021). Hewan coba diberikan perlakuan selama 7 hari secara terus menerus satu kali sehari dengan maksud mengetahui fungsi ginjal ditinjau dari parameter ureum darah.

Setelah pemberian dosis pada masing-masing kelompok tikus, pengambilan darah dilakukan guna memperoleh serum yang nantinya akan dilakukan pemeriksaan menggunakan fotometer. Pengambilan darah dilakukan dengan cara mengambil sampel darah melalui dari sinus orbitalis mata. Dengan metode ini darah volume yang diambil akan lebih banyak (Baroroh, 2011).

Hasil pengambilan darah kemudian disentrifuse guna memperoleh serum yang kemudian dianalisi menggunakan fotometer dengan reagen kit pemeriksanaa ureum.

Pada pemeberian dosis I dan III terjadi penurunan kadar ureum. Tikus yang diberikan sediaan ekstrak etanol Bunga Telang (Clitoria ternatea L.) sebagai nefroprotektor dapat mencegah peningkatan kadar ureum yang diakibatkan oleh induksi parasetamol yang dapat mengganggu homeostasis yang ada dalam tubuh. Meningkatnya cairan tubuh terutama $\mathrm{Ca}^{2+}$ pada intra sel seperti pada Phospolipase, Protease, Endonuklease dan Triphosphatase adenosis dapat menyebabkan kerusakan sel. 
Terjadinya kerusakan sel pada ginjal ini dapat menyebabkan fungsi dari ginjal mengalami gangguan yaitu kemampuan ginjal untuk menyaring ureum dapat berkurang dan mengakibatkan kadar ureum meningkat (Rasyad, 2012).

Korelasi antara perbedaan dosis pemberian dengan penurunan kadar ureum diukur berdasarkan analisis statistik satu arah. Dari data yang diperoleh menggunakan analisis statistik satu arah, Dosis I dan Dosis III mempunyai nilai yang cukup signifikan (Gambar 1) dengan nilai $\mathrm{P}<0,05$. Pemberian ekstrak etanol bunga telang pada Dosis I dan Dosis III menunjukkan penurunan kadar ureum darah tikus bila dibandingkan dengan kontrol tetapi masih dalam kadar normal ureum yaitu 41,64-62,67 mg/dL

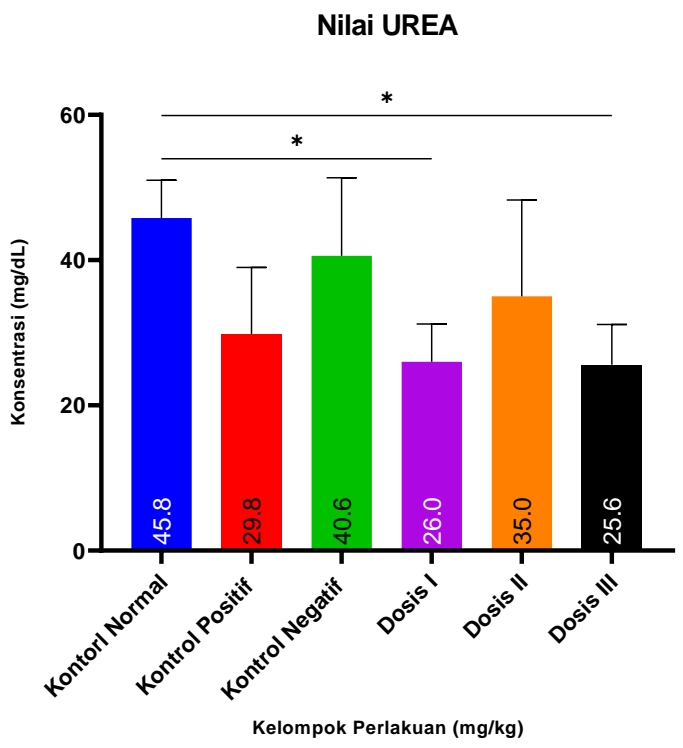

Gambar 1. Nilai Ureum Pada Uji Statistik ANOVA

\section{KESIMPULAN}

Dari penelitian yang telah dilakukan dapat diambil kesimpulan bahwa Dosis I dengan konsentrasi $100 \mathrm{mg} / \mathrm{kg}$ dan Dosis III dengan konsentrasi $300 \mathrm{mg} / \mathrm{kg}$ mengalami penurunan kadar ureum darah tikus bila dibandingkan dengan kontrol tetapi masih dalam kadar normal ureum yaitu 41,64-62,67 $\mathrm{mg} / \mathrm{dL}$.

\section{DAFTAR PUSTAKA}

Amalia, R., Setyawati, A. N., \& Ngestiningsih, D. (2017). Analisis Ekstrak Buah Kiwi (Actinidia Deliciosa) Pada Kadar Ureum Dan Kreatinin Serum Tikus Wistar Yang Diinduksi Parasetamol. Diponegoro Medical Journal, Jurnal Kedokteran Diponegoro. 6 (2): Hal 1186-1195. 
Andriani, D., \& Murtisiwi, L. (2020). Uji Aktivitas Antioksidan Ekstrak Etanol 70\% Bunga Telang (Clitoria ternatea L) dari Daerah Sleman dengan Metode DPPH. Pharmacon: Jurnal Farmasi Indonesia. 17 (1): Hal 70-76.

Anjani, M., AS, N. A., \& Mubarakati, N. J. (2021). Studi Subkronik. 28 Hari: Uji Toksisitas Ekstrak Metanolik Kombinasi Scurulla atropurpurea dan Dendrophthoe pentandra terhadap Kerusakan Fungsi Ginjal Tikus Wistar Betina. Biosaintropis, BioscienceTropic. 6 (2): Hal 58-63.

Baroroh, F., Aznam, N., \& Susanti, H. (2011). Uji efek antihiperglikemik ekstrak etanol daun kacapiring (Gardenia augusta, Merr) pada tikus putih jantan galur wistar. Pharmaciana edisi Mei 2011. 1 (1): Hal 43-53.

Budiasih KS. (2017). Kajian Potensi Farmakologis Bunga Telang (Clitoria ternatea). Prosiding Seminar Nasional Kimia UNY 2017.

Cahyaningsih, E., Yuda, P. E. S. K., \& Santoso, P. (2019). Skrining Fitokimia Dan Uji Aktivitas Antioksidan Ekstrak Etanol Bunga Telang (Clitoria ternatea L.) Dengan Metode Spektrofotometri Uv-Vis. Jurnal Ilmiah Medicamento. 5 (1): Hal 51-57.
Canayakin, D., Bayir, Y., Kilic Baygutalp, N., Sezen Karaoglan, E., Atmaca, H. T., Kocak Ozgeris, F. B., \& Halici, Z. (2016). Paracetamol-induced nephrotoxicity and oxidative stress in rats: the protective role of Nigella sativa. Pharmaceutical biology. 54 (10): Hal 2082-2091.

Cekmen, M., Ilbey, Y. O., Ozbek, E., Simsek, A., Somay, A., \& Ersoz, C. (2009). Curcumin prevents oxidative renal damage induced by acetaminophen in rats. Food and Chemical Toxicology. 47 (7): Hal 1480-1484.

Cone, E. J. and Gorodetzky, C. W. (2008). Drug-Induced Nephrotoxicity. Drug Metabolism and Disposition. 3 (5): Hal 417-418.

Dokumacioğlu, E., Iskender, H., Aktaş, M. S., Hanedan, B., Dokumacioğlu, A., Mazlum Şen, T., \& Saral, S. (2016). The effect of sulforaphane on the levels of serum cystatin-c in acetaminopheninduced nephrotoxicity in rats. Dicle Medical Journal. 43 (3): Hal 383-389.

El-Shafey, M. M., Abd-Allah, G. M., Mohamadin, A. M., Harisa, G. I., \& Mariee, A. D. (2015). Quercetin protects against acetaminopheninduced hepatorenal toxicity by 
reducing reactive oxygen and nitrogen species. Pathophysiology. 22 (1): Hal 49-55.

Kurniadi, E., Rousdy, D. W., \& Yanti, A. H. 2018. Aktivitas nefroprotektif ekstrak metanol buah lakum (Cayratia trifolia (L.) Domin) terhadap induksi parasetamol. Jurnal Labora Medika. 2 (1): Hal 14-21.

Madinah, N., Nozmo, M., \& Ezekiel, I. (2015). The protective effects of aqueous extract of Carica papaya seeds in paracetamol induced nephrotoxicity in male wistar rats. African health sciences. 15 (2): Hal 598-605.

Marpaung, A. M. (2020). Tinjauan manfaat bunga telang (Clitoria Ternatea L.) bagi kesehatan manusia. Journal of Functional Food and Nutraceutical. Hal 63-85.

Mazer, M., \& Perrone, J. (2008). Acetaminophen-induced nephrotoxicity: pathophysiology, clinical manifestations, and management. Journal of Medical Toxicology. 4 (1): Hal 2-6.

Palimbong S, Pariama AS. Potensi Ekstrak Bunga Telang (Clitoria ternatea Linn) sebagai Pewarna pada Produk Tape Ketan. J. Sains. Kes. 2 (3): Hal 228-35.
Pratiwi, E. R., Rahmandani, S. O. A., Ibrahim, A. R., \& Isbandiyah, I. (2020). Potensi Ekstrak Bunga Telang (Clitoria ternatea) Sebagai Pencegah Acute Kidney Injury (AKI). CoMPHI Journal: Community Medicine and Public Health of Indonesia Journal. 1(2): Hal 92-100.

Rasyad, A. A., Mahendra, P., \& Hamdani, Y. (2012). Uji nefrotoksik dari ekstrak etanol biji mahoni (Swietenia Mahagoni Jacq.) terhadap tikus putih jantan Galur Wistar. Jurnal penelitian sains. 15 (2).

Santos-Sánchez, N. F., Salas-Coronado, R., Villanueva-Cañongo, $\quad$ C., $\quad \&$ Hernández-Carlos, B. (2019). Antioxidant compounds and their antioxidant mechanism (pp. 1-28). London, UK: IntechOpen.

Stollings, J. L., Wheeler, A. P., \& Rice, T. W. (2016). Incidence and characterization of acute kidney injury after acetaminophen overdose. Journal of critical care. 35: Hal 191-194.

Syafitri, I. N., Hidayati, I. R., \& Pristianty, L. (2017). Hubungan tingkat pengetahuan terhadap penggunaan obat parasetamol rasional dalam swamedikasi. Jurnal Farmasi Dan Ilmu Kefarmasian Indonesia. 4 (1): Hal 19-26. 
Zain et al.;Aktivitas Nefroprotektif Ekstrak Etanol.....Pharmacoscript Volume 4 No. 2, Agustus 2021

Wang, L., Ma, R., Guo, Y., Sun, J., Liu, H., Zhu, R., \& Gao, S. (2017). Antioxidant effect of Fructus Ligustri Lucidi aqueous extract in ovariectomized rats is mediated through Nox4-ROS-NF- $\kappa B$ pathway. Frontiers in Pharmacology. 8: Hal 266.

Winarti, N., Laila Vifta, R., \& Susilo, J. (2020). Uji Aktivitas Antioksidan Ekstrak Bunga Telang (Clitoria ternatea L.) Dengan Pelarut Etanol Dan Etil Asetat Menggunakan Metode Frap (Ferric Reducing Antioxidant Power) (Doctoral dissertation, Universitas Ngudi Walyo. 